\title{
Cerebral and somatic oxygen saturation in pediatric cardiac patients with delayed sternal closure
}

\author{
L Kovacikova*, A Bicianova, P Skrak, M Zahorec \\ From ESICM LIVES 2015 \\ Berlin, Germany. 3-7 October 2015
}

\section{Introduction}

Near-infrared spectroscopy offers non-invasive online monitoring of tissue oxygenation in a wide range of clinical scenarios.

\section{Objectives}

The purpose of this study was to assess near-infrared spectroscopy-derived cerebral and somatic oxygen saturations $\left(\mathrm{rSO}_{2} \mathrm{~b}\right.$ and $\left.\mathrm{rSO}_{2} \mathrm{~s}\right)$ in children after cardiac surgery with delayed sternal closure (DSC). We hypothesized that $\mathrm{rSO}_{2} \mathrm{~b}$ and $\mathrm{rSO}_{2} \mathrm{~S}$ correlate with other indicators of hemodynamic compromise after DSC.

\section{Methods}

We studied 43 postoperative children (median age, 8 days; range, 1-148 days) with DSC. The most common cardiac diagnosis was hypoplastic left heart syndrome (30\%). $\mathrm{rSO}_{2} \mathrm{~b}$ and $\mathrm{rSO}_{2} \mathrm{~S}$ and other hemodynamic and metabolic parameters were analyzed on the day of surgery, 3 days after surgery (POD1-3), and prior to and 24 hours after DSC.

\section{Results}

$\mathrm{rSO}_{2} \mathrm{~b}$ increased at 12 hours $(\mathrm{p}=0.0039)$, and $\mathrm{rSO}_{2} \mathrm{~s}$ did not change compared to data immediately after surgery. Deficit base decreased $(\mathrm{p}=0.016)$ and standard bicarbonates increased $(\mathrm{p}=0.016)$ on POD1, lactate decreased $(\mathrm{p}=0.0001)$ and diuresis increased $(\mathrm{p}=0.013)$ on POD2, heart rate decreased $(\mathrm{p}=0.035)$ on POD3. There was no change in systemic arterial blood pressure, left atrial pressure (LAP) and central venous pressure (CVP), arteriovenous oxygen saturation difference (a-vO2 dif.), $\mathrm{pH}$,
$\mathrm{paO}_{2}$, and $\mathrm{paCO}_{2}$. Vasoactive inotropic score was lower on POD2 and 3 compared to the day of surgery ( $\mathrm{p}=$ 0.041 and $p=0.048)$. DSC resulted in an increase in LAP, CVP, a-vO2 dif., and base deficit $(\mathrm{p}<0.05)$. Increase in LAP lasted 24 hours, other changes were present during 18 hours. $\mathrm{rSO}_{2} \mathrm{~b}$ and $\mathrm{rSO}_{2} \mathrm{~S}$ were lower at 1 6 hour and during 24 hours, respectively $(\mathrm{p}<0.05)$. There was no change in lactate levels. $\mathrm{pH}$ and standard bicarbonate were lower and vasoactive inotropic score was higher compared to preclosure values $(\mathrm{p}<0.05)$. $\mathrm{rSO}_{2} \mathrm{~b}$ and $\mathrm{rSO}_{2} \mathrm{~S}$ values did not correlate with lactate and a-vO2 dif. values.

\section{Conclusions}

In pediatric cardiac patients with left open chest $\mathrm{rSO}_{2} \mathrm{~b}$ values increase on the day of surgery and $\mathrm{rSO}_{2} \mathrm{~S}$ do not change. DSC is associated with a decrease in $\mathrm{rSO}_{2} \mathrm{~b}$ and $\mathrm{rSO}_{2} \mathrm{~S}$ that persists for 6 and 24 hours, respectively. $\mathrm{rSO}_{2} \mathrm{~b}$ and $\mathrm{rSO}_{2} \mathrm{~S}$ values do not correlate with other metabolic indicators of hemodynamic status.

Published: 1 October 2015

\section{References}

1. Özker E, Saritaş B, Vuran C, et al: Delayed Sternal Closure After Pediatric Cardiac Operations; Single Center Experience: a Retrospective Study. J Thorac Cardiovasc Surg 2012, 7:102.

2. Horvath R, Shore S, Schultz SE, et al: Cerebral and somatic oxygen saturation decrease after delayed sternal closure in children after cardiac surgery. J Thorac Cardiovasc Surg 2010, 139:894-900.

doi:10.1186/2197-425X-3-S1-A950

Cite this article as: Kovacikova et al: Cerebral and somatic oxygen saturation in pediatric cardiac patients with delayed sternal closure. Intensive Care Medicine Experimental 2015 3(Suppl 1):A950. 